\title{
CRITICAL APPROACH TO INDIAN EDUCATION SYSTEM WITH REFERENCE TO THE THEORIES OF EDUCATION OF KAUTILYA AND PLATO
}

\section{Dr. Dyuti Yajnik}

In this paper it is observed that there should be a synthesis of all prevailing as well as Ideally thought education systems. For this purpose, the book by Yogendra K. Sharma 'The Doctrines of the Great Indian Educators' is taken as a basic book for the research and further some websites are being used for the evaluation.

Broadly analyzing, our personality is comprises of basic three elements Thinking, Feeling and Willing and accordingly there are three Yoga in Geeta Jnanayoga, Bhaktiyoga and Karmayoga. As it is said that "Dharmo hi tesham adhiko vishesho - that is Dharma (duty as well as religion) is for human being only, it becomes necessary to develop our humanhood by developing these three basic traits of personality. Education is supposed to do the job. But in this paper I concluded with the thought that all systems of education had develop the skills and ability to earn but somehow lacks the teaching and learning of the basic metaphysics of religions and moral values and thereby lacks the feeling of peaceful coexistence with universal brotherhood. We are fail to produce a real 'Humans' and rather produced 'Human Resources' ! The need for the day is to develop a synthesized form of education which include traditional as well as modern pattern. Therefore, in this paper this forms are discussed with holistic view.

Though Kautila was not during the Vaidic period, his education policy appears very relevant regarding certain aspects which are emphasized by Indian as well 
as western wise philosopher. Therefore, here it becomes necessary to mention his education system, which is as under :

\section{Kautily Presented the Indian Tradition of Education :}

Kautilya indicates the entire circle of the then knowledge as being made up of four divisions called,

(1) Anvikshaki,

(2) Trayi,

(3) Varta,

(4) Dandaniti.

Each of these divisions comprises a number of subjects or sciences. Subjects of Study. The name Anvikshaki stands for the sciences derived from subjective or metaphysical speculation involving keen introspection. Three such different subjects or systems of thought and philosophy are known to Kautilya viz. Samkhya, Yoga, and Lokayata. 35 The division called Trayi; is, of course, made up of the three Vedas, Sama, Rig, and Yajus. The Atharvaveda and Itihasa veda are also known as Vedas. The Vedangas are also enumerated, viz. Siksha, Kalpa, Vyakarana, Nirukta, Chhandas, and Jyotisha. The rules of studentship are clearly mentioned.

Studentship was open to the first three castes. The first Ashrama or stage of life obligatory upon all the three castes was that of studentship. The duties of the student comprised (1) repetition of sacred texts, (2) worship of fire, (3) ablution, (4) observance of the vow of begging, (5) service to the teacher to the end of his life and in his absence to his son or to the fellow-disciple. Certain moral and mental qualities are insisted upon as constituting the eligibility for studentship, implying the duties as mentioned above. Learning is regarded as a process of discipline which cannot operate successfully except upon suitable material 
[Kriyahi dravyam vinayati nadravyam]. Learning cannot train up any student unless he is intent upon or keen about the following requisites thereof, viz.

(1) desire to learn,

(2) receiving the lessons daily,

(3) understanding them,

(4) retaining them in memory,

(5) reflection upon them,

(6) exercise of judgement or discrimination, and

(7) love of truth.

Kautilya is primarily concerned with the education of the prince belonging to the ruling Kshatriya caste for which the following details are given. The studentship of a prince is to continue only up to his sixteenth year when he must marry.

During this necessarily shortterm of his studentship, he is to pursue a threefold course of studies.

(1) The first course is in the department of the Trayi and Anvikshaki, i.e. religious and philosophical subjects. The teachers of this course must be Sishtas, i.e. teachers whose authority was acknowledged as much for their character as for their learning.

(2) The second course of studies was connected with Varta, i.e. subjects relating to agriculture, cattle-rearing, the trade. The prince must study these subjects under practical experts, viz. the heads of the several actual government departments administering the interests pertaining thereto.

(3) The third course for the prince was in Dandaniti or the science and art of government. The teachers should be those who were equally proficient in the theory and practice of administration. 
Even after his marriage, the prince was to continue his studies for which a timetable is given.

(I) In the forenoon he is to receive training in the military arts connected with the four departments of the army, viz. the elephant, the horse, the chariot, and the infantry (which implies training in the art of handling various weapons of war).

(II) The afternoon he is to spend in listening to discourses on Itihasa, which included, according to Kautilya the following subjects, viz. Purana, Itivritta, Akhyayiika, Udaharana, Dharmasastra, and Arthasastra.

(III) During the available intervals of day and night he is to acquire new and revise old knowledge. In the case of lessons not grasped, he must listen to repeated instruction.

Besides these studies, companionship with men of ripe wisdom and culture is also prescribed for the prince as the root of mental and moral growth.

As regards the qualifications of the Purohita, it is stated that he must have the culture and character of a family, well versed in traditional learning, fully educated in the Vedas, the six Vedangas, the science of portents and omens, the art of administration, and able, by his knowledge and application of the Atharvan remedies, to ward off calamities due to divine and human agencies.

Here it is necessary to evaluate the Indian education systems propounded by wise philosophers of India, with Greek education system propounded by a wise philosopher Plato.

\section{Plato's Education Policy}


Greek philosopher Plato's Republic is a dialogue which discusses the education necessary to produce such a society. It is an education of a strange sort - he called it paideia. Nearly impossible to translate into modern idiom, paideia refers to the process whereby the physical, mental and spiritual development of the individual is of paramount importance. It is the education of the total individual.

He distinguished between the Reality presented to us by our senses - sight, touch, taste, sound and smell - and the essence or Form of that Reality. In other words, Reality is always changing - knowledge of Reality is individual, it is particular, it is knowledge only to the individual knower, it is not Universal.

There are 3 sources of knowledge: TM

(1) Knowledge obtained from senses,i.e. knowledge of objects , colours, taste, touch etc. But Plato does not consider this as real knowledge. An opinion regarding any object, but this knowledge cannot be relied upon as the views of every person differs regarding the same object.

(2) Knowledge through mind or wisdom - it is the highest degree of knowledge which includes virtues like truth, goodness and beauty. This knowledge is idealistic and is based on original thinking. The characteristic of knowledge is that it is found in the form of universal truth.

(3) The highest goal of education, Plato believed, is the knowledge of Good; to nurture a man to a better human being, it is not merely an awareness of particular benefits and pleasures.

Faced with the problem of determining the class of each individual, Plato suggested various kinds of tests to be conducted at different age levels. 
- In the first place, primary education will be given to all between the ages of seven and twenty, following which a test shall be administered to everyone. Those who fail the test are to be sent to labour in the various occupations and productive trades.

- The successful candidates will be sent to the armed forces where training will be imparted to them for the next ten years. This will again be followed by a test, the failures will be compelled to remain in the armed forces while the successful ones will be sent to join the government.

- Then this governing class will be subjected to further education in science. Later on, one from among the governing class will be elected as the philosopher administrator whose task will be to look after government and education of the state.

-This individual will occupy the highest position in the land, his word will be the law of the land. Apart from this supreme individual, all other members of the governing class will continue to receive education throughout their lives, most of this education consisting of teachings in philosophy.

- The object of Platonic education is therefore moral and political. Tt is not an apprenticeship for know-how but an education in life skills.

\section{PLATONIC SYSTEM OF SCHOOLS}

\section{AGE \\ SCHOOL \\ SPECIAL DEVELOPMENT OR STUDIES}

Birth to 3years Infancy

Bodily growth, sensory life, no fear, child reacts to pleasure and pain

4 to 6 years Nursery

Play, fairy tales, nursery rhymes, myths,

get

rid of self-will

6 to 13 years Elementary

school Play, poetry, reading, writing, singing, 
dancing, religion, manners, numbers, geometry

13 to 16 years Instrumental

Music Play the cithara, religious hymns,

memorize poetry (esp religious and patriotic), arithmetic (theory)

16 to 20 years Gymnastics and the military

Formal gymnastics and military training. No

20 TO 30 years Sciences

intellectual training.

Coordination of reason and habits; interrelating the physical sciences

30 to 35 years Dialectic

Philosophy, Psychology, Sociology, government, law , education

35 t0 50 years Service to State

50 to end Philosophers

Higher Philosophy

\section{Education Policies of Independent India}

With the brief introduction to the education system in Greek as well as Vaidik tradition, here it is necessary to evaluate that in the contemporary education systems, the ideal of which was given by the Education Commissions of Independent India.

"The Government of India appointed a university Education Commission under the chairmanship of Dr. Radhakrishnan in November 1948. The Commission made a number of significant recommendations on various aspects of higher education and submitted its report in August 1949. In the rapidly changing contemporary world, universities are undergoing profound changes in their scope, function and organization and are in a process of rapid evolution." 
Secondly, "The National Policy on Education (NPE) is a policy formulated by the Government of India to promote education amongst India's people. The policy covers elementary education to colleges in both rural and urban India. The first NPE was promulgated in 1968 by the government of Prime Minister Indira Gandhi, and the second by Prime Minister Rajiv Gandhi in 1986."

"Since the country's independence in 1947, the Indian government sponsored a variety of programmes to address the problems of illiteracy in both rural and urban India. Maulana Abul Kalam Azad, India's first Minister of Education, envisaged strong central government control over education throughout the country, with a uniform educational system."

The Union government established the University Education Commission (1948-1949), the Secondary Education Commission (1952-1953) and the Kothari Commission (1964-68) to develop proposals to modernise India's education system.

Indian Education Commission (1964-1966), popularly known as Kothari Commission, was an ad hoc commission set up by the Government of India to examine all aspects of the educational sector in India, to evolve a general pattern of education and to advise guidelines and policies for the development of education in India. It was formed on 14 July 1964 under the chairmanship of Daulat Singh Kothari, then chairman of the University Grants Commission. The terms of reference of the commission was to formulate the general principles and guidelines for the development of education from primary level to the highest and advise the government on a standardized national pattern of education in India. However, the medical and legal studies were excluded from the purview of the commission. The tenancy of the commission was from 1964 to 1966 and the report was submitted by the commission on 29 June 1966. 


\section{Commission of 1968 -}

It was based on the report and recommendations of the Education Commission (1964-1966), the government of Prime Minister Indira Gandhi announced the first National Policy on Education in 1968, which called for a "radical restructuring" and equalize educational opportunities in order to achieve national integration and greater cultural and economic development.

\section{Commission of 1986 -}

Having announced that a new policy was in development in January, 1985, the government of Prime Minister Rajiv Gandhi introduced a new National Policy on Education in May, 1986. ${ }^{[4]}$ The new policy called for "special emphasis on the removal of disparities and to equalise educational opportunity," especially for Indian women, Scheduled Tribes (ST) and the Scheduled Caste (SC) communities.

\section{Commission of 1992 -}

The 1986 National Policy on Education was modified in 1992 by the P.V. Narasimha Rao government. In 2005, Prime Minister Manmohan Singh adopted a new policy based on the "Common Minimum Programme" of his United Progressive Alliance (UPA) government.

According to Dr. Radhakrishnan, "It is my earnest desire that the Commission should survey all aspects of educational system at all levels and give suggestions that may help the educational system in progressing at all levels. According to Kothari Commission, "One of the important social objectives of education is to equalize opportunity, enabling the backward or underprivileged 
classes and individuals to use education as a tool for improvement of their social and economic condition".

The most important and urgent reform needed in education is to transform it, to relate it to the life, needs and aspirations of the people and thereby make a powerful instrument of social, economic and cultural transformation, necessary for realization of the national goals. For this purpose the commission has suggested the following objectives of education:

\section{The four main themes of the commission were:}

1. Increase in Productivity

2. Promoting social and National Integration

3. Education and Modernization

4. Developing social, moral and spiritual values

\section{Regarding the Limitations of Contemporary Education System - Swami Vivekananda (1863-1902)}

In the recent times, when we have already the knowledge of the Ideal education systems. Though we have added many things which were not included in the previous education systems, still, we are fail to produce the Great Humans through this prevailing education system. Regarding this failure, Swami Vivekananda observe that there are many limitations in this system.

"Against the contemporary educational system the chief objection raised by Vivekananda was that it turned men into slaves, capable of slavery and nothing else. About the prevailing university education, he remarked that it was not better than an efficient machine for rapidly turning out clerks. It deprived people of their faith and belief. The English educated people believed that Gita was false and the Vedas were no more significant than rural folk lore." 
Vivekananda also criticized the contemporary system of education from the humanistic viewpoint. He was a humanist and pleaded for education for manmaking. Such was not the education propounded by the British.

Therefore, Vivekananda condemned it. He remarked, "It is not a man-making education, it is merely and entirely a negative education. A negative education or any training that is based on negation, is worse than death. The child is taken to school and the first thing he learns is that his father is a fool, the second thing that his grandfather is lunatic, the third thing that all his teachers are hypocrites, the fourth, that all the sacred books are lies. By the time he is sixteen he is a mass of negation, lifeless and boneless. ....Every man of originality that has been produced has been educated elsewhere, and not in this country, or they have gone to the old universities once more to cleanse themselves of superstitions."

Therefore, there must be some reformation in the social as well as education systems. Swami Dayananda tried to re-established the age-long, rich Vaidic tradition of Indan education system which is generally known as 'gurukul parampara'.

\section{Conclusion}

In short, human personality is comprises of three elements - Thinking, Feeling and Willing, and if we develop such education system which can develop these three in as many as people by synthesizing Indian as well as western and traditional as well as modern education policies, then wisdom will prevail. In other words, if we combine the Plato's Ideal of Education with the Vaidic Ideal of Education, we can have what Shri Aurobindo called "A Gnostic Society" where the major population will be of 'wise' citizens and other will faithfully obey these 'wise citizens'. 


\section{References :}

(1) Yogendra K. Sharma, The Doctrines of the Great Indian Educators, Kanishka Publishers-Distributors, 4697/5-21 A, Ansari Road, Daryaganj New Delhi-110002. ISBN 81-7391-505-9 2002

(2) Altekar, A.S.-Education in India, Varanasi, Nawal Kishore\&Bros., 1957.

(3) Mayer Frederick-A History of Educational Thought (chapter 4), OHIO Charles E. Merrill Books.

(4) Munshi, K.M.-Foundations of Indian Culture, Bombay, Bhartiya Vidya Bhawan, 1962.

(5) Radha Kumud Mukherji-Ancient Indian Education, Delhi, Motilal, Banarsidas, 1951.

(6) Saiydin, K.G.-The Humanist Tradition in Indian Educational Thought, Bombay, Asia Publishing House, 1960.

(7) Sharma, R.N.-Philosophy of Education, Delhi, Atlantic, 1996. Sharma, R.N.-Problems of Education, Delhi, Atlantic, 1996.

(8) Sharma, Y.K.- History and Problems of Education, Vols. I\&II, New Delhi, Kanishka Publishers, Distributors, 2001.

(9) Bawa, Chhajju Singh - The Teaching of the Arya Samaj, Lahore, 1908.

(10) Bawa, Chhajju Singh-The Life and Teachings of Swami Dayananda Saraswati, Lahore, 1923.

(11) Farquhar-Modern Religious Moments in India, pp. 101-129, New York, 1915.

(12) Satya Prakash-A Critical Study of Philosophy of Dayananda, Vedic Pustakalaya, Ajmer, 1938.

(13) Article shared by Senthil Kumar

\section{Dr. Dyuti Yajnik Associate Professor, Dept.of Philosophy, Gujarat Unviersity, Ahmedabad}

